\title{
Optimization of aqueous enzymatic extraction of oil from shrimp processing by-products using response surface methodology
}

\author{
Chen WENWEI ${ }^{1 *}$, Huang GUANGRONG ${ }^{1}$, Jia ZHENBAO ${ }^{1}$, Hong $\mathrm{YAO}^{2}$
}

\begin{abstract}
The aqueous enzymatic extraction (AEE) of oil from shrimp processing by-products was investigated. Four kinds of proteases, including alkaline protease, neutral protease, flavor protease and compound protease, were applied to hydrolysis shrimp processing by-products. The results showed that flavor protease was the best hydrolysis enzyme for shrimp processing by-products to obtain high oil recovery. The influences of four factors, including enzyme amount, liquid/solid ratio, hydrolysis time and hydrolysis temperature, on shrimp oil extraction yield were also studied. The flavor enzyme hydrolysis condition was optimized as following: enzyme amount of $2.0 \%(\mathrm{w} / \mathrm{w})$, liquid/solid ratio of $9.0 \mathrm{ml} / \mathrm{g}$, hydrolysis time of $2.6 \mathrm{~h}$ and hydrolysis temperature of $50{ }^{\circ} \mathrm{C}$. Under these optimum hydrolysis conditions, the experimental oil extraction yield was $88.9 \%$.
\end{abstract}

Keywords: shrimp processing by-products; shrimp oil; aqueous enzymatic extraction; response surface methodology.

Pratical Application: Aqueous enzymatic extraction of oil from shrimp processing by - products.

\section{Introduction}

Shrimps are processed in seafood export processing units, generating large number of by-products, such as shrimp head and shrimp shells. Utilization of such large quantities of shrimp processing discards, such as for oil recovery, would not only reduce the disposal problems associated with these wastes, but also enhance the economy of shrimp processing.

Several studies have investigated to obtain carotenoids (Sowmya \& Sachindra, 2012; Sachindra \& Mahendrakar, 2005), astaxanthin (Pu et al., 2010; Handayani et al., 2008), polyunsaturated fatty acids (Treyvaud Amiguet et al., 2012), protein (Ferrer et al., 1996), peptides (Zhao et al., 2013; Huang et al., 2011), antioxidants (Seymour et al., 1996), chitin biopolymers (Pinelli Saavedra et al., 1998) and salt-fermented shrimp sauce (Kim et al., 2005) from shrimp processing by-products. However, to our knowledge, there are few studies focused on shrimp oil extraction from shrimp processing by-products.

Generally, conventional methods of producing edible oil from oilseeds were to use expeller pressing and organic solvent extraction. Mechanical extraction can result in low oil recovery and denatured proteins, and the use of organic solvents may cause solvent residue and non-friendly to environment. The AEE for oil extraction as an emerging technology, enables simultaneous recovery of oil and protein from most oil materials (Li et al., 2013a). Enzymes are useful for the extraction of oil due to their high efficiency and specificity. Enzyme preparations hydrolyse and rupture the cell wall constituents and improve the release of intracellular contents. AEE technology has been applied for oils extraction from seed crops, such as pumpkin (Jiao et al., 2014), oil palm fruit (Teixeira et al., 2013), bayberry
(Zhang et al., 2012), peanut (Li et al., 2011; Jiang et al., 2010), watermelon (Sui et al., 2011), sesame (Latif \& Anwar, 2011), flax (Long et al., 2011), wheat (Li et al., 2010), and soybean (Towa et al., 2010).

Large-scale production required consumption of massive fresh raw shrimp, and at the same time, produced a large number of shrimp waste. Therefore, effective method of oil extraction from shrimp processing by-products has higher economic value.

However, to the best of our knowledge, there are few studies about the AEE of oil from shrimp processing by-products. Therefore, the objective of this study was to investigate the optimal AEE conditions of oil from shrimp processing by-products by response surface methodology (RSM). And the fatty acid compositions of AEE extracted shrimp processing by-products oil was studied.

\section{Materials and methods}

\subsection{Materials}

Shrimp processing by-products were from Yingzhou Seafood Corporation (Zhoushan city, Zhejiang province, China). After dried by vacuum at $75^{\circ} \mathrm{C}$, they were ground in a powder, and dispersed through 60 mesh sieve. The powders were sealed in plastic containers and stored in a refrigerator at $4{ }^{\circ} \mathrm{C}$ until extraction.

Alkaline protease $(200 \mathrm{U} / \mathrm{mg})$, neutral protease $(500 \mathrm{U} / \mathrm{mg})$ purchased from Wuxi Xuemei Enzyme Preparation Technology Co., Ltd. (Wuxi, China); Flavor protease $(50 \mathrm{U} / \mathrm{mg})$ and 
compound protease $(50 \mathrm{U} / \mathrm{mg}$ ) from Novozymes company, China. Additionally, other reagents of analytical and optical grades were purchased from Sinopharm Chemical Reagents Co. (Shanghai, China).

\subsection{Aqueous enzyme extraction}

The shrimp processing by-product powders were commixed with $0.2 \mathrm{M}$ phosphate buffer solution at a designed ratio. Enzyme was added and the mixtures were incubated in a water bath at proper temperature for suitable time. The suspension was centrifuged $\left(4^{\circ} \mathrm{C}, 10,000 \mathrm{~g}\right)$ for $20 \mathrm{~min}$. The layers of free oil and emulsion phase were collected separately. Total free oil and the emulsion phase was then demulsified by foam suppressor HS508 and separately further centrifuged to get free oil. Total oils were collected and weighed.

\subsection{Shrimp oil extraction yield calculation}

The content of crude fat of shrimp processing by-products was measured by Soxhlet extraction method (Abdulkarim et al., 2005) (Equation 1).

shrimp oil extraction yield $(\%)=\frac{\text { the weight of the shrimp oil }}{\text { the weight of the crude fat }} \times 100 \%$

\subsection{GC-MS analyses of fatty acid compositions}

The fatty acid compositions of shrimp oils were analysed by GC-MS. Prior to injection, the obtained oil was converted to its fatty acid methyl esters (FAME) through alkaline transmethylation by using $\mathrm{KOH}$ in methanol as a methylating agent (Li et al., 2013b). GC-MS analysis was performed using agilent 5975B GC-MS gas chromatography/mass spectrometer, equipped with an HP-5 silica capillary column $(30 \mathrm{~m} \times 0.32 \mathrm{~mm}$ I.D.; film thickness $0.2 \mu \mathrm{m}$ ). The detail operating conditions were carried out as following: helium gas flow rate $3 \mathrm{~mL} / \mathrm{min}$; split ratio 1:10; injector temperature $250^{\circ} \mathrm{C}$; injection volume $1 \mu \mathrm{L}$; oven temperature progress from 110 to $230^{\circ} \mathrm{C}$ at the rate of $15^{\circ} \mathrm{C} / \mathrm{min}$; detector temperature $280{ }^{\circ} \mathrm{C}$; ion source temperature $220^{\circ} \mathrm{C}$; ionisation mode used at electronic impact $70 \mathrm{eV}$; mass range $50-500 \mathrm{~m} / \mathrm{z}$. Identification of chemical constituents of shrimp oils was based on the comparisons of their retention indices and mass spectra with publish data and computer matching the mass spectra fragmentation patterns with those stored in mass spectral library NIST05 provided by the software of GC-MS system. Relative percentage compositions of oils were calculated from the total ion chromatograms by a computerized integrator.

\subsection{Experimental design and statistical analysis}

The preliminary range of the extraction variables were determined through single factor experiments. Response surface methodology (RSM) based on central composite rotatable design (CCRD) was applied to evaluate the effects of four independent variables, enzyme amount $\left(\mathrm{X}_{1}\right)$, liquid/solid ratio $\left(\mathrm{X}_{2}\right)$, hydrolysis time $\left(\mathrm{X}_{3}\right)$, hydrolysis temperature $\left(\mathrm{X}_{4}\right)$, and their interaction on the measured response, extraction yield $(\mathrm{Y})$. The independent variables were coded at five levels $(-2,-1,0,+1,+2)$, and the complete design consisted of 31 experimental points including 7 replications of the centre points. The coded levels of the independent variables used in the RSM design were listed in Table 1.
Table 1. Analytical factors and levels for RSM.

\begin{tabular}{|c|c|c|c|c|c|}
\hline \multirow{2}{*}{ Factors } & \multicolumn{5}{|c|}{ Levels } \\
\hline & -2 & -1 & 0 & +1 & +2 \\
\hline $\begin{array}{l}\text { Enzyme amount } \\
\left(\%, w / W, X_{1}\right)\end{array}$ & 1.0 & 1.5 & 2.0 & 2.5 & 3.0 \\
\hline $\begin{array}{l}\text { Liquid/solid ratio } \\
\left(\mathrm{ml} / \mathrm{g}, \mathrm{X}_{2}\right)\end{array}$ & $4: 1$ & $6: 1$ & $8: 1$ & $10: 1$ & $12: 1$ \\
\hline Time $\left(\mathrm{h}, \mathrm{X}_{3}\right)$ & 1.5 & 2.0 & 2.5 & 3.0 & 3.5 \\
\hline $\begin{array}{l}\text { Temperature } \\
\left({ }^{\circ} \mathrm{C}, \mathrm{X}_{4}\right)\end{array}$ & 30 & 40 & 50 & 60 & 70 \\
\hline \multicolumn{6}{|c|}{ The extraction yield of shrimp oil by RSM } \\
\hline Test numbers & $\mathrm{x}_{1}$ & $\mathrm{x}_{2}$ & $\mathrm{x}_{3}$ & $\mathrm{x}_{4}$ & $\begin{array}{c}\text { Extraction } \\
\text { yield (\%) }\end{array}$ \\
\hline 1 & -1 & -1 & -1 & -1 & 63.49 \\
\hline 2 & 1 & -1 & -1 & -1 & 64.86 \\
\hline 3 & -1 & 1 & -1 & -1 & 67.16 \\
\hline 4 & 1 & 1 & -1 & -1 & 67.61 \\
\hline 5 & -1 & -1 & 1 & -1 & 65.78 \\
\hline 6 & 1 & -1 & 1 & -1 & 68.07 \\
\hline 7 & -1 & 1 & 1 & -1 & 69.45 \\
\hline 8 & 1 & 1 & 1 & -1 & 65.37 \\
\hline 9 & -1 & -1 & -1 & 1 & 55.72 \\
\hline 10 & 1 & -1 & -1 & 1 & 56.15 \\
\hline 11 & -1 & 1 & -1 & 1 & 64.86 \\
\hline 12 & 1 & 1 & -1 & 1 & 66.24 \\
\hline 13 & -1 & -1 & 1 & 1 & 55.69 \\
\hline 14 & 1 & -1 & 1 & 1 & 63.94 \\
\hline 15 & -1 & 1 & 1 & 1 & 68.07 \\
\hline 16 & 1 & 1 & 1 & 1 & 70.83 \\
\hline 17 & -2 & 0 & 0 & 0 & 61.96 \\
\hline 18 & 2 & 0 & 0 & 0 & 69.17 \\
\hline 19 & 0 & -2 & 0 & 0 & 50.64 \\
\hline 20 & 0 & 2 & 0 & 0 & 76.33 \\
\hline 21 & 0 & 0 & -2 & 0 & 60.46 \\
\hline 22 & 0 & 0 & 2 & 0 & 70.13 \\
\hline 23 & 0 & 0 & 0 & -2 & 64.86 \\
\hline 24 & 0 & 0 & 0 & 2 & 52.94 \\
\hline 25 & 0 & 0 & 0 & 0 & 89.17 \\
\hline 26 & 0 & 0 & 0 & 0 & 88.15 \\
\hline 27 & 0 & 0 & 0 & 0 & 87.84 \\
\hline 28 & 0 & 0 & 0 & 0 & 88.31 \\
\hline 29 & 0 & 0 & 0 & 0 & 88.87 \\
\hline 30 & 0 & 0 & 0 & 0 & 88.26 \\
\hline 31 & 0 & 0 & 0 & 0 & 88.42 \\
\hline
\end{tabular}

The second-order polynomial model proposed for the response surface analysis of the designed experiment was explained by Equation 2:

$Y=\beta_{0}+\sum_{i=1}^{4} \beta_{i} X_{i}+\sum_{i=1}^{4} \beta_{i i} X_{i}^{2}+\sum_{i=1}^{3} \sum_{j=i+1}^{4} \beta_{i j} X_{i} X_{j}$

Where $\mathrm{Y}$ is the extraction yield; $\beta_{0}, \beta_{i}, \beta_{i i}$ and $\beta_{i j}$ are the coefficients of intercept, linear, quadratic, and interactive terms respectively; while $X_{i}$ and $X_{i}$ are the coded values of the four independent variables. 
To analyze the multiple regression and variance, a regression equation between variables and response, and numerical optimum the procedure, the SAS software program (version 9.0, SAS Institute Inc., Cary, NC, USA) was employed.

\section{Results and discussion}

\subsection{Choice of enzyme types}

As presented in Figure 1, more oil was recovered using hydrolytic enzymes (66.4-76.1\%), when compared with the control (40.6\%, no enzyme). The recovery rate of shrimp oil was higher significantly when using flavor protease, which might be attributed to breakdown of the protein networks of oleosin-based membranes that surround lipid bodies, and in turn it liberated more oils. It had also proved that the use of protease resulted in higher oil yield than without enzyme treatment (Mat Yusoff et al., 2016; Latif et al., 2008).

\subsection{Optimization of AEE by RSM}

Aqueous enzymatic extraction conditions of oil from shrimp processing by-products were optimized by RSM. On the basis of the experimental results of CCD (Table 1) and regression analysis, a second-order polynomial equation was established to estimate the relationship between the oil extraction yield and variables. The model could be expressed as (Equation 3):

$$
\begin{aligned}
& Y=88.43+1.78 X_{1}+4.70 X_{2}+2.33 X_{3}-2.64 X_{4}- \\
& 5.67 X_{1}^{2}-6.19 X_{2}^{2}-5.73 X_{3}^{2}-7.33 X_{4}^{2}- \\
& 1.71 X_{1} X_{2}-0.62 X_{1} X_{3}+1.38 X_{1} X_{4}- \\
& 1.31 X_{2} X_{3}+2.53 X_{2} X_{4}+1.21 X_{3} X_{4}
\end{aligned}
$$

Where, the $\mathrm{X}_{1}, \mathrm{X}_{2}, \mathrm{X}_{3}$ and $\mathrm{X}_{4}$ correspond to the coded values of the four independent variables (enzyme amount, liquid/solid ratio, hydrolysis time and temperature).

The results of the analysis of the models were summarized in Table 2 and Table 3 . The determination coefficient $\left(\mathrm{R}^{2}=0.9810\right)$ was showed by ANOVA of the quadratic regression model, indicating that only $1.9 \%$ of the total variations were not explained by the model. At the same time, a very low value coefficient of 2.45 of the variation $(\mathrm{CV})$ clearly indicated a very high degree

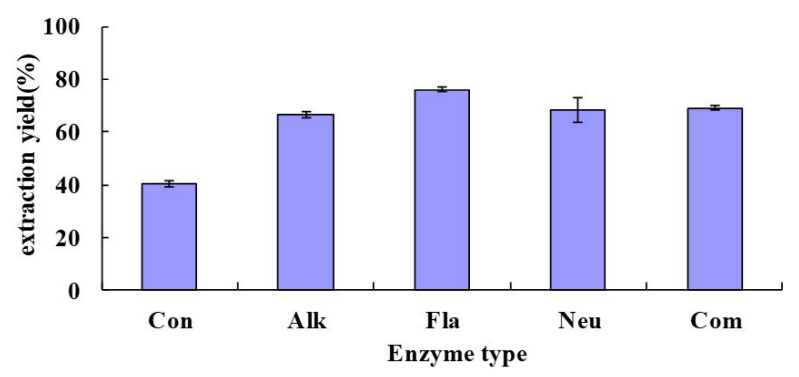

Figure 1. The effects of different enzymes on the oil yield by AEE. Con: control; Alk: alkaline protease; Fla: flavor protease; Neu: neutral protease; Com:compound protease. The other parameters were set as follows: enzyme concentration $1.5 \%$, liquid/solid ratio $10 \mathrm{~mL} / \mathrm{g}$, temperature $50{ }^{\circ} \mathrm{C}$ and extraction time $3.0 \mathrm{~h}$. of precision and a good deal of reliability of the experimental values. The model was found to be adequate for prediction within the range of experimental variables.

All the linear terms $\left(\mathrm{X}_{1}, \mathrm{X}_{2}, \mathrm{X}_{3}, \mathrm{X}_{4}\right)$, all quadratic terms $\left(\mathrm{X}_{1}{ }^{\star} \mathrm{X}_{1}, \mathrm{X}_{2}{ }^{*} \mathrm{X}_{2}, \mathrm{X}_{3}{ }^{\star} \mathrm{X}_{3}, \mathrm{X}_{4}{ }^{\star} \mathrm{X}_{4}\right)$ and cross product $\left(\mathrm{X}_{2}{ }^{*} \mathrm{X}_{1}, \mathrm{X}_{4}{ }^{*} \mathrm{X}_{2}\right)$ were highly significant, with very small $\mathrm{P}$-values $(\mathrm{P}<0.01)$. The cross product $\left(\mathrm{X}_{3}{ }^{*} \mathrm{X}_{2}, \mathrm{X}_{4}{ }^{*} \mathrm{X}_{1}\right)$ were significant, with very small $\mathrm{P}$-values $(\mathrm{P}<0.05)$ and the other term coefficients were not significant $(\mathrm{P}>0.05)$.

Three-dimensional (3D) response surface plots presenting the effects of the four independent variables on the response were shown in Figure 2. Each of the plots in Figure 2 was drawn to illustrate two of the variables and their interaction affecting the dependent variable with another two variables fixed (0 level).

They provide a means of visualizing relationship between the responses and experimental levels of each variable and the type of interactions between the two test variables. The shapes of the contour plots, circular or elliptical, indicate whether the mutual interactions between the variables are significant or not. Circular contour plots indicate that the interactions between the corresponding variables are negligible, while elliptical contour plots indicate that the interactions between the corresponding variables are significant.

Table 2. The ANOVA results of RSM.

\begin{tabular}{lrccrc}
\hline \multicolumn{1}{c}{ Source } & $\begin{array}{c}\text { Sum of } \\
\text { squares }\end{array}$ & df & $\begin{array}{c}\text { Mean } \\
\text { square }\end{array}$ & $F$ value & $P$-value \\
\hline Model & 3994.70 & 14 & 0.9810 & 59.10 & $<0.0001^{*}$ \\
Linear & 561.99 & 4 & 0.1380 & 29.10 & $<.0001$ \\
Quadratic & 3293.11 & 4 & 0.8087 & 170.52 & $<.0001$ \\
Cross product & 139.60 & 6 & 0.0343 & 4.82 & 0.0055 \\
Lack of fit & 45.85 & 9 & 5.09 & 1.14 & 0.4433 \\
Pure error & 31.40 & 7 & 4.49 & & \\
Total Error & 77.25 & 16 & 4.83 & & \\
$\mathrm{R}^{2}=0.9810$ coefficient of the variation $=2.45$ & & \\
\hline
\end{tabular}

Table 3. Regression coefficients of the predicted quadratic polynomial model.

\begin{tabular}{crrrr}
\hline Parameter & Estimate & $\begin{array}{c}\text { Standard } \\
\text { Error }\end{array}$ & t Value & Pr $>|t|$ \\
\hline Intercept & -409.813398 & 29.462978 & -13.23 & $<.0001$ \\
$\mathrm{X}_{1}$ & 100.297469 & 10.745341 & 9.33 & $<.0001$ \\
$\mathrm{X}_{2}$ & 27.468951 & 2.686335 & 10.23 & $<.0001$ \\
$\mathrm{X}_{3}$ & 122.698531 & 11.355402 & 10.81 & $<.0001$ \\
$\mathrm{X}_{4}$ & 4.900483 & 0.626109 & 7.83 & $<.0001$ \\
$\mathrm{X}_{1}{ }^{*} \mathrm{X}_{1}$ & -22.667028 & 1.647062 & -13.76 & $<.0001$ \\
$\mathrm{X}_{2}{ }^{*} \mathrm{X}_{1}$ & -1.709650 & 0.572149 & -2.99 & 0.0087 \\
$\mathrm{X}_{2}{ }^{*} \mathrm{X}_{2}$ & -1.546689 & 0.102941 & -15.02 & $<.0001$ \\
$\mathrm{X}_{3}{ }^{*} \mathrm{X}_{1}$ & -2.483599 & 2.288597 & -1.09 & 0.2939 \\
$\mathrm{X}_{3}{ }^{*} \mathrm{X}_{2}$ & -1.308400 & 0.572149 & -2.29 & 0.0362 \\
$\mathrm{X}_{3}{ }^{*} \mathrm{X}_{3}$ & -22.937028 & 1.647062 & -13.93 & $<.0001$ \\
$\mathrm{X}_{4}{ }^{*} \mathrm{X}_{1}$ & 0.276461 & 0.116845 & 2.37 & 0.0309 \\
$\mathrm{X}_{4}{ }^{*} \mathrm{X}_{2}$ & 0.126365 & 0.029211 & 4.33 & 0.0005 \\
$\mathrm{X}_{4}{ }^{*} \mathrm{X}_{3}$ & 0.241711 & 0.116845 & 2.07 & 0.0551 \\
$\mathrm{X}_{4}{ }^{*} \mathrm{X}_{4}$ & -0.073330 & 0.004118 & -17.81 & $<.0001$ \\
\hline & & & &
\end{tabular}



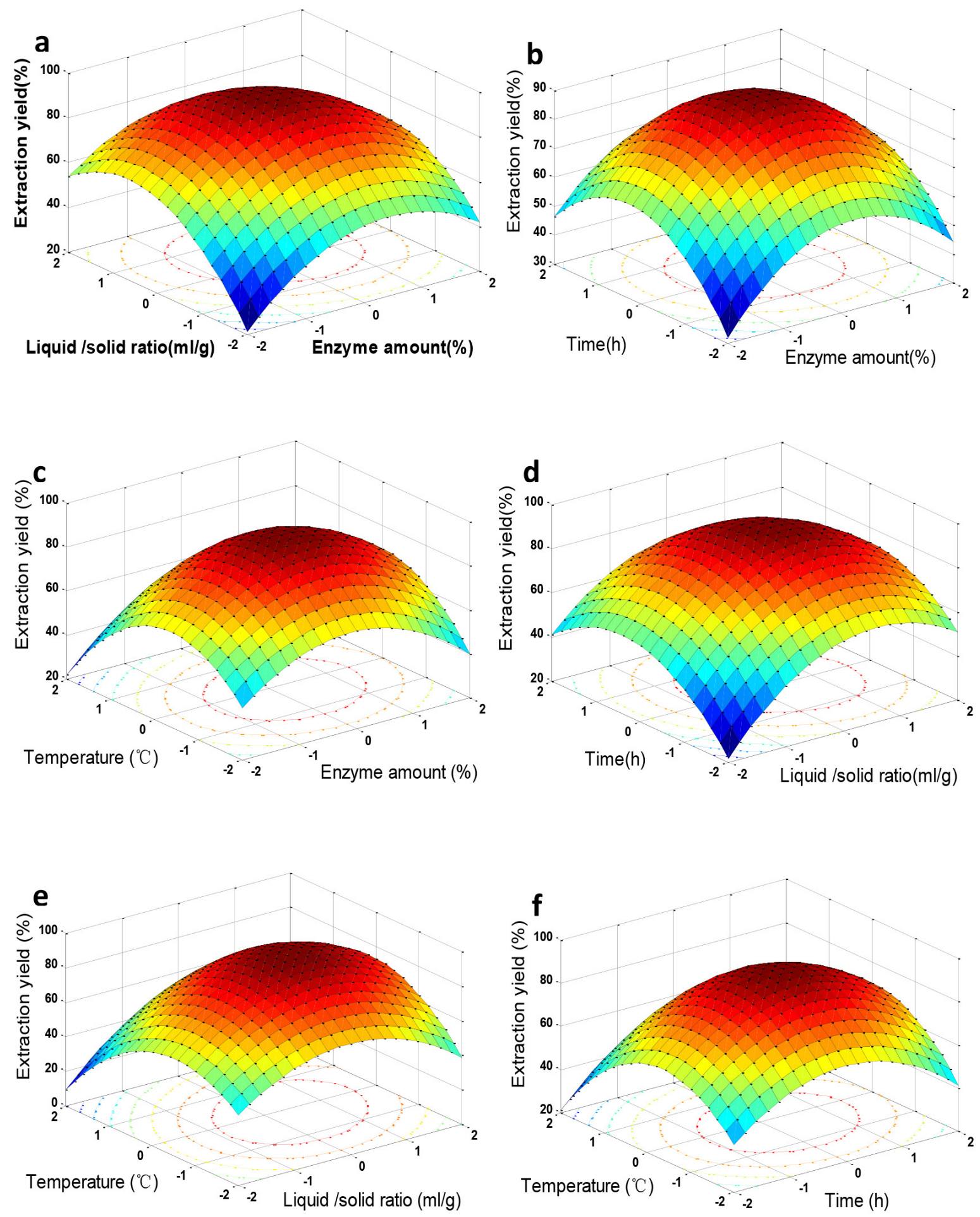

Figure 2. Effects of different variables (X1: enzyme amount, X2: liquid /solid ratio, X3: time, X4: temperature) on the response (extraction yield) presented in response surface $(3 \mathrm{D})$ plots.

Through these $3 \mathrm{D}$ response surface and their respective contour plots, it is very easy and convenient to understand the interactions between two variables and to locate their optimum ranges.

As shown in Figure 2a, enzyme amount and liquid/solid ratio affected significantly extraction yield, and the oil extraction yield reached the highest when enzyme amount around at $2.0 \%$ and liquid/solid ratio at $8 \mathrm{ml} / \mathrm{g}$.

As shown in Figure 2b, extraction yield increased with rising temperature as the rate of enzyme-catalyzed reactions. However, at higher temperatures $\left(50-70^{\circ} \mathrm{C}\right)$, the yield decreased sharply, because the enzymes would be denatured at higher 
temperatures. A similar trend in extraction yield was observed as shown in Figure 2e and $2 \mathrm{f}$.

Figure 2C describes the interactive effect of hydrolysis time and enzyme amount. Hydrolysis time exhibited an important effect on the oil yield. As shown in Figure $2 \mathrm{C}$ and D, extraction yield increased with extended time at a given enzyme amount and liquid/solid ratio in an early stage of extraction. With the increasement of enzyme amount, the extraction yield rose at first, then decreased slightly when the enzyme amount reached its high levels.

Based on the mathematical predicted model, the optimal experimental conditions were as following: enzyme amount of $2.04 \%(w / w)$, liquid/solid ratio of $8.66 \mathrm{ml} / \mathrm{g}$, hydrolysis time of $2.58 \mathrm{~h}$ and temperature at $48.97^{\circ} \mathrm{C}$. Considering the actual operation, enzyme amount, liquid/solid ratio, time and temperature were modified to $2.0 \%, 9.0 \mathrm{ml} / \mathrm{g}, 2.6 \mathrm{~h}$ and $50{ }^{\circ} \mathrm{C}$, respectively.

The reliability of the theoretical model was verified under optimal parameters. A yield of $88.9 \pm \mathbf{1 . 0} \%$ was obtained from these experiments, which was a good fit for the value forecasted $\mathbf{8} \mathbf{8 9 . 6} \%)$ by the regression model. Therefore, the oil extraction conditions achieved by RSM were reliable and practical.

\subsection{Fatty acid composition analysis of shrimp oil}

In order to know the fatty acid compositions of enzyme-assisted extraction oil from shrimp processing byproduct, GC/MS was used after the sample was methylated. The results was shown in Table 4. The AEE of shrimp oil contained a total of 11 major fatty acids, as following: C13:0 (ginkgo acid) accounted for 3.26\%; C14:0 (nutmeg acid) accounted for 3.32\%; C14:1 (tetradecenoic acid) accounted for 1.85\%; C16:0 (hexadecanoic acid) accounted for 20.35\%; C16:1 (zoomaric acid) accounted for 1.89\%; C18:0 (stearic acid) accounted for 12.71\%; C18:1 (oleic acid) accounted for 26.25\%; C18:2 (linoleic acid) accounted for 11.87\%; C18:3 (Octadecatrienoic acid) accounted for 1.43\%; C20:5 (eicosapentaenoic acid ethyl ester, EPA) accounted for 7.81\%; C22:6 (docosahexaenoic acid DHA) accounted for $9.26 \%$.

The types and contents of saturated fatty acids in our results were similar to the previously reported values (Sánchez-Camargo et al., 2012), but obtained different content in the EPA and DHA when compared to the krill oil (Colombo-Hixson et al., 2011;

Table 4. Percent fatty acid composition.

\begin{tabular}{ccc}
\hline No. & Fatty acids & Relative content \\
\hline 1 & $13: 0$ & 3.26 \\
2 & $14: 0$ & 3.32 \\
3 & $14: 1$ & 1.85 \\
4 & $16: 0$ & 20.35 \\
5 & $16: 1$ & 1.89 \\
6 & $18: 0$ & 12.71 \\
7 & $18: 1$ & 26.25 \\
8 & $18: 2$ & 11.87 \\
9 & $18: 3$ & 1.43 \\
10 & $20: 5$ & 7.81 \\
11 & $22: 6$ & 9.26 \\
\hline
\end{tabular}

Phleger et al., 2002). The difference of fatty acids composition may due to the Farmed or wild, region, climatic conditions, species, and processing treatment (Sampaio et al., 2006; Harlioglu et al., 2016)

\section{Conclusion}

In this study, the oil was firstly extracted from shrimp processing by-products by aqueous enzymatic method. The extraction conditions were optimized by RSM. We concluded that extraction yield was dependent on all the linear terms (enzyme amount, liquid/solid ratio, time and temperature), and all the quadratics (enzyme amount, liquid/solid ratio, time and temperature), and cross product (the interactions between enzyme amount and liquid/solid ratio, liquid /solid ratio and temperature, liquid /solid ratio and time, enzyme amount and temperature). A polynomial regression model was used to describe the experimental results, and based on the proposed model, whose availability and accuracy was verified by validation experiments, the optimal extraction conditions for extraction yield were enzyme amount, liquid/solid ratio, time, temperature as $2.0 \%(\mathrm{w} / \mathrm{w}), 9.0 \mathrm{ml} / \mathrm{g}, 2.6 \mathrm{~h}$ and $50{ }^{\circ} \mathrm{C}$. Under the optimum conditions, the experimental extraction yield was $88.9 \%$. Furthermore, the GC analysis showed that the shrimp oil composited by eleven fatty acids.

\section{Acknowledgements}

This research was supported by Public Welfare Research Project of Zhejiang Province (2015C32041; LGN18C200025; LGN18C200006).

\section{References}

Abdulkarim, S. M., Long, K., Lai, O. M., Muhammad, S. K. S., \& Ghazali, H. M. (2005). Some physico-chemical properties of Moringa oleifera seed oil extracted using solvent and aqueous enzymatic methods. Food Chemistry, 93(2), 253-263. http://dx.doi.org/10.1016/j. foodchem.2004.09.023.

Colombo-Hixson, S. M., Olsen, R. E., Milley, J. E., \& Lall, S. P. (2011). Lipid and fatty acid digestibility in Calanus copepod and krill oil by Atlantic halibut (Hippoglossus hippoglossus L.). Aquaculture (Amsterdam, Netherlands), 313(1-4), 115-122. http://dx.doi. org/10.1016/j.aquaculture.2010.12.020.

Ferrer, J., Paez, G., Marmol, Z., Ramones, E., Garcia, H., \& Forster, C. F. (1996). Acid hydrolysis of shrimp-shell wastes and the production of single cell protein from the hydrolysate. Bioresource Technology, 57(1), 55-60. http://dx.doi.org/10.1016/0960-8524(96)00057-0.

Handayani, A. D., Sutrisno, Indraswati, N., \& Ismadji, S. (2008). Extraction of astaxanthin from giant tiger (Panaeus monodon) shrimp waste using palm oil: sudies of extraction kinetics and thermodynamic. Bioresource Technology, 99(10), 4414-4419. http://dx.doi.org/10.1016/j. biortech.2007.08.028. PMid:17911016.

Harlioglu, A. G., Aydin, S., \& Yilmaz, O. (2016). Fatty acid, cholesterol and fat-soluble vitamin composition of wild and captive freshwater crayfish (Astacus leptodactylus). Food Science \& Technology International, 18(1), 93-100. PMid:22328124.

Huang, G. G., Ren, Z. Y., \& Jiang, J. X. (2011). Separation of iron-binding peptides from shrimp processing by-products hydrolysates. Food and Bioprocess Technology, 4(8), 1527-1532. http://dx.doi.org/10.1007/ s11947-010-0416-3. 
Jiang, L. H., Hua, D., Wang, Z., \& Xu, S. (2010). Aqueous enzymatic extraction of peanut oil and protein hydrolysates. Food and Bioproducts Processing, 88(2-3), 233-238. http://dx.doi.org/10.1016/j. fbp.2009.08.002.

Jiao, J., Li, Z. G., Gai, Q. Y., Li, X. J., Wei, F. Y., Fu, Y. J., \& Ma, W. (2014). Microwave-assisted aqueous enzymatic extraction of oil from pumpkin seeds and evaluation of its physicochemical properties, fatty acid compositions and antioxidant activities. Food Chemistry, 147, 17-24. http://dx.doi.org/10.1016/j.foodchem.2013.09.079. PMid:24206680.

Kim, J.-S., Shahidi, F., \& Heu, M.-S. (2005). Tenderization of meat by saltfermented sauce from shrimp processing by-products. Food Chemistry, 93(2), 243-249. http://dx.doi.org/10.1016/j.foodchem.2004.09.022.

Latif, S., \& Anwar, F. (2011). Aqueous enzymatic sesame oil and protein extraction. Food Chemistry, 125(2), 679-684. http://dx.doi. org/10.1016/j.foodchem.2010.09.064.

Latif, S., Diosady, L. L., \& Anwar, F. (2008). Enzyme-assisted aqueous extraction of oil and protein from canola (Brassica Napus L.) seeds. European Journal of Lipid Science and Technology, 110(10), 887-892. http://dx.doi.org/10.1002/ejlt.200700319.

Li, H., Song, C., Zhou, H., Wang, N., \& Cao, D. (2010). Optimization of the aqueous enzymatic extraction of wheat germ oil using response surface methodology. Journal of the American Oil Chemists' Society, 88(6), 809-817. http://dx.doi.org/10.1007/s11746-010-1731-6.

Li, Y., Jiang, L. Z., Sui, X. N., Qi, B. K., \& Han, Z. Y. (2011). The study of ultrasonic-assisted aqueous enzymatic extraction of oil from peanut by response surface method. Procedia Engineering, 15, 4653-4660. http://dx.doi.org/10.1016/j.proeng.2011.08.873.

Li, Y., Zhang, Y., Wang, M., Jiang, L., \& Sui, X. (2013a). Simplex-centroid mixture design applied to the aqueous enzymatic extraction of fatty acid-balanced oil from mixed seeds. Journal of the American Oil Chemists' Society, 90(3), 349-357. http://dx.doi.org/10.1007/ s11746-012-2180-1.

Li, J., Zu, Y. G., Luo, M., Gu, C. B., Zhao, C. J., Efferth, T., \& Fu, Y. J. (2013b). Aqueous enzymatic process assisted by microwave extraction of oil from yellow horn (Xanthoceras sorbifolia Bunge.) seed kernels and its quality evaluation. Food Chemistry, 138(4), 2152-2158. http://dx.doi.org/10.1016/j.foodchem.2012.12.011. PMid:23497870.

Long, J., Fu, Y., Zu, Y., Li, J., Wang, W., Gu, C., \& Luo, M. (2011). Ultrasound-assisted extraction of flaxseed oil using immobilized enzymes. Bioresource Technology, 102(21), 9991-9996. http://dx.doi. org/10.1016/j.biortech.2011.07.104. PMid:21890349.

Mat Yusoff, M., Gordon, M. H., Ezeh, O., \& Niranjan, K. Masni, M. Y., Michael, H. G., Onyinye, E., \& Keshavan, N. (2016). Aqueous enzymatic extraction of Moringa oleifera oil. Food Chemistry, 211, 400-408. http://dx.doi.org/10.1016/j.foodchem.2016.05.050. PMid:27283648.

Phleger, C. F., Nelson, M. M., Mooney, B. D., \& Nichols, P. D. (2002). Interannual and between species comparison of the lipids, fatty acids and sterols of Antarctic krill from the US AMLR Elephant Island survey area. Comparative Biochemistry and Physiology. B, Comparative Biochemistry, 131(4), 733-747. http://dx.doi.org/10.1016/ S1096-4959(02)00021-0. PMid:11923086.

Pinelli Saavedra, A., Toledo Guillén, A. R., Esquerra Brauer, I. R., Luviano Silva, A. R., \& Higuera Ciapara, I. (1998). Methods for extracting chitin from shrimp shell waste. Archivos Latinoamericanos de Nutricion, 48(1), 58-61. PMid:9754407.

$\mathrm{Pu}$, J., Bechtel, P. J., \& Sathivel, S. (2010). Extraction of shrimp astaxanthin with flaxseed oil: effects on lipid oxidation and astaxanthin degradation rates. Biosystems Engineering, 107(4), 364-371. http:// dx.doi.org/10.1016/j.biosystemseng.2010.10.001.

Sachindra, N. M., \& Mahendrakar, N. S. (2005). Process optimization for extraction of carotenoids from shrimp waste with vegetable oils. Bioresource Technology, 96(10), 1195-1200. http://dx.doi.org/10.1016/j. biortech.2004.09.018. PMid:15683912.

Sampaio, G. R., Bastos, D. H. M., Soares, R. A. M., Queiroz, Y. S., \& Torres, E. A. F. S. (2006). Fatty acids and cholesterol oxidation in salted and dried shrimp. Food Chemistry, 95(2), 344-351. http:// dx.doi.org/10.1016/j.foodchem.2005.02.030.

Sánchez-Camargo, A. P., Meireles, M. Â. A., Ferreira, A. L. K., Saito, E., \& Cabral, F. A. (2012). Extraction of $\omega-3$ fatty acids and astaxanthin from Brazilian redspotted shrimp waste using supercritical CO2 + ethanol mixtures. The Journal of Supercritical Fluids, 61, 71-77. http://dx.doi.org/10.1016/j.supflu.2011.09.017.

Seymour, T. A., Li, S. J., \& Morrissey, M. T. (1996). Characterization of a natural antioxidant from shrimp shell waste. Journal of Agricultural and Food Chemistry, 44(3), 682-685. http://dx.doi.org/10.1021/ jf950597f.

Sowmya, R., \& Sachindra, N. M. (2012). Evaluation of antioxidant activity of carotenoid extract from shrimp processing byproducts by in vitro assays and in membrane model system. Food Chemistry, 134(1), 308-314. http://dx.doi.org/10.1016/j.foodchem.2012.02.147.

Sui, X. N., Jiang, L. Z., Li, Y., \& Liu, S. (2011). The research on extracting oil from watermelon seeds by aqueous enzymatic extraction method. Procedia Engineering, 15, 4673-4680. http://dx.doi.org/10.1016/j. proeng.2011.08.875.

Teixeira, C. B., Macedo, G. A., Macedo, J. A., Silva, L. H. M., \& Rodrigues, A. M. C. (2013). Simultaneous extraction of oil and antioxidant compounds from oil palm fruit (Elaeis guineensis) by an aqueous enzymatic process. Bioresource Technology, 129, 575-581. http:// dx.doi.org/10.1016/j.biortech.2012.11.057. PMid:23274221.

Towa, L. T., Kapchie, V. N., Hauck, C., \& Murphy, P. A. (2010). Enzymeassisted aqueous extraction of oil from isolated oleosomes of soybean flour. Journal of the American Oil Chemists' Society, 87(3), 347-354. http://dx.doi.org/10.1007/s11746-009-1503-3.

Treyvaud Amiguet, V., Kramp, K. L., Mao, J. Q., McRae, C., Goulah, A., Kimpe, L. E., Blais, J. M., \& Arnason, J. T. (2012). Supercritical carbon dioxide extraction of polyunsaturated fatty acids from Northernshrimp (Pandalus borealis Kreyer) processing by-products. Food Chemistry, 130(4), 853-858. http://dx.doi.org/10.1016/j. foodchem.2011.07.098.

Zhang, Y. L., Li, S., Yin, C. P., Jiang, D. H., Yan, F. F., \& Xu, T. (2012). Response surface optimisation of aqueous enzymatic oil extraction from bayberry (Myrica rubra) kernels. Food Chemistry, 135(1), 304308. http://dx.doi.org/10.1016/j.foodchem.2012.04.111.

Zhao, J., Huang, G. G., \& Jiang, J. X. (2013). Purification and characterization of a new DPPH radical scavenging peptide from shrimp processing by-products hydrolysate. Journal of Aquatic Food Product Technology, 22(3), 281-289. http://dx.doi.org/10.1080/10498850.2011.645125. 